\title{
Pengaruh Metode Bermain Peran Terhadap Keterampilan Berbicara Anak Usia 5 - 6 Tahun di TK Ilmi Insani
}

Received : 14 Maret 2020

Revised : 15 Mei 2020

Accepted : 2 Juni 2020

\author{
Mustika Ayu ${ }^{1}$, Nasriah ${ }^{2}$ \\ Fakultas Ilmu Pendidikan \\ Universitas Negeri Medan \\ Jln. Willem Iskandar Psr V Medan Estate \\ E-mail : mustikaayu@gmail.com
}

\begin{abstract}
Abstrak. Dalam penelitian ini yang menjadi sebuah masalah adalah keterampilan berbicara anak yang belum berkembang dengan baik. Hal tersebut dikarenakan kurangnya kesempatan yang diberikan guru kepada anak untuk berinteraksi langsung baik dengan guru maupun dengan teman bermainnya, kurangnya penerapan metode pembelajaran yang bervariasi, seperti metode bermain peran yang memberikan kebebasan pada anak untuk berinteraksi dengan temannya dan menumbuhkan rasa percaya diri anak untuk terampil dalam berhubungan dengan orang lain. Penelitian ini bertujuan untuk mengetahui keterampilan berbicara anak usia 5-6 tahun di TK Ilmi Insani Medan.

Jenis penelitian ini adalah penelitian post test only control design. Penelitian ini dilakukan dengan menggunakan dua kelas kelompok yang memiliki karakteristik yang sama yaitu kelas B1 dan kelas B2. Penentuan sampel kelas dilakukan secara acak (random) dengan jumlah sampel tiap kelas sebanyak 13 anak.Variabel bebas adalah metode bermain peran sedangkan variabel terikat adalah keterampilan berbicara. Instrumen pengumpulan data yaitu pedoman observasi. Analisis data mengunakan uji-t. Dan observasi dilakukan pengobservasi dengan pedoman observasi yang telah disediakan. Dengan taraf nyata $\alpha=0,05$.

Berdasarkan hasil analisis data diperoleh rata-rata nilai pada kelas eksperimen 10,07 dengan nilai rata-rata tertinggi anak adalah 3 dan nilai rata-rata terendah anak 8 , sehingga keterampilan berbicara anak pada kelas eksperimen memperoleh perbedaan yang signifikan. Sedangkan nilai rata-rata pada kelas kontrol 8,38 dengan nilai rata-rata tertinggi 2,5 dan nilai terendah 1,5, sehingga keterampilan berbicara anak pada kelas kontrol memperoleh perbedaan yang signifikan. Berdasarkan hasil tersebut hipotesis menyatakan bahwa pembelajaran menggunakan metode bermain peran berpengaruh secara signifikan terhadap keterampilan berbicara anak yaitu dari hasil uji hipotesis diperoleh $t_{\text {hitung }}>t_{\text {tabel }}$ yaitu 3,869 $>1,711$ pada taraf $\alpha=0.05$. Dengan demikian metode bermain peran berpengaruh secara signifikan terhadap keterampilan berbicara anak usia 5-6 tahun di TK Ilmi Insani Jl. Letda Sudjono Medan.
\end{abstract}

Kata Kunci: Bermain Peran, Keterampilan berbicara

\section{PENDAHULUAN}

Salah satu bentuk pengembangan bahasa atau yang dikenal dengan keterampilan bahasa yaitu berbicara. Keduanya merupakan bagian dari proses komunikasi. Berbicara merupakan salah satu aspek keterampilan bahasa yang bersifat produktif, artinya suatu kemampuan yang dimiliki seseorang untuk menyampaikan gagasan, pikiran atau perasaan sehingga gagasan-gagasan yang ada dalam pikiran pembicara dapat dipahami orang lain.

Menurut Laura Dyer (2004 : 2) bahasa merupakan "suatu system simbolis yang digunakan untuk mewakili pikiran seseorang. Hal tersebut mengacu pada kosakata, tata 
bahasa, dan kondisi sosial yang mengatur cara kita berkomunikasi melalui berbagai sarana seperti berbicara, memberikan isyarat tubuh, dan menulis

Permasalahan yang muncul dilapangan secara umum keterampilan anak belum sesuai dengan yang diharapkan. Hal ini disebabkan keterbatasan kata-kata yang diketahui dan informasi yang didengar dari orang-orang disekitarnya, hal ini terlihat masih ada anak yang diam, bengong, kadang termangu kalau ditanya oleh guru atau teman di sekolah, bahkan oleh orang tua atau orang-orang yang ada disekitar, anak elum mampu menyebutkan dan menjelaskan tentang sesuatuhal, terbata-bata takut salah kalau berbicara, karena anak belum memiliki kosa kata yang memadai atau pelajaran yang kurang variatif, kalau hal itu dibiarkan terus menerus anak akan mempunyai kesulitan dalam menggunakan bahasa, terutama dalam berkomunikasi secara lisan di masyarakat. Selain itu, ketika anak diminta menceritakan tentang pengalamannya sehari-hari, belum beraninya anak untuk bercerita didepan teman-temannya atau di depan kelas, dan masih terdapat anak yang bersifat pasif ketika diminta berbicara.

Berdasarkan observasi yang dilakukan peneliti TK Ilmi Insani Medan keterampilan berbicara anak masih belum sesuai dengan yang diharapkan, seperti masih ada anak yang belum lancar berbicara. Misalnya, ketika anak diminta menceritakan tentang pengalamannya sehari-hari, belum beraninya anak untuk tampil bercerita didepan temantemannya atau didepan kelas, dan masih terdapat anak yang bersikap pasif ketika diminta berbicara.

\section{METODOLOGI PENELITIAN}

Metode penelitian yang digunakan dalam penelitian ini adalah metode penelitian eksperimen.Desain dalam penelitian ini adalah True EksperimentalDesign, dengan bentuk Postest-Only Control Design dalam model ini terdapat kelompok eksperimen dan kelompok Kontrol yang dipilih secara random. Sugiyono (2010:117) mengatakan populasi adalah wilayah generalisasi yang terdiri atas : objek/subjek yang mempunyai kualitas dan karakteristik tertentu yang ditetapkan peneliti untuk dipelajari dan kemudian ditarik kesimpulannya. Dari definisi diatas, maka populasi dalam penelitian ini adalah seluruh anak di TK Ilmi Insani Letda Sudjono T.A 2015/2016. Adapun anak kelompok B terdiri dari 2 kelas yaitu kelas B1 berjumlah 13 anak, kelas B2 berjumlah 13 anak. Dengan jumlah keseluruhan anak sebanyak 26 anak.

Dalam penelitian ini teknik pengumpulan data yang digunakan adalah observasi. Metode observasi dilakukan dengan cara mengamati dan mencatat semua aktivitas anak pada proses kegiatan kolase di kelas. Observasi dilakukan pada anakkelompok Buntuk memperoleh data anak yang berkaitan dengan aspek-aspek kreativitas anak.Penyusunan data dilakukan dengan memuat namaanak.Tugas observer memberi tanda checklist $(\checkmark)$ pada skor yang di dapat melalui pedoman observasi yang dibuat. Dari observasi yang dilakukan maka diperoleh data tentang keterampilan berbicara 
Tabel 1. Kisi - Kisi Observasi Anak

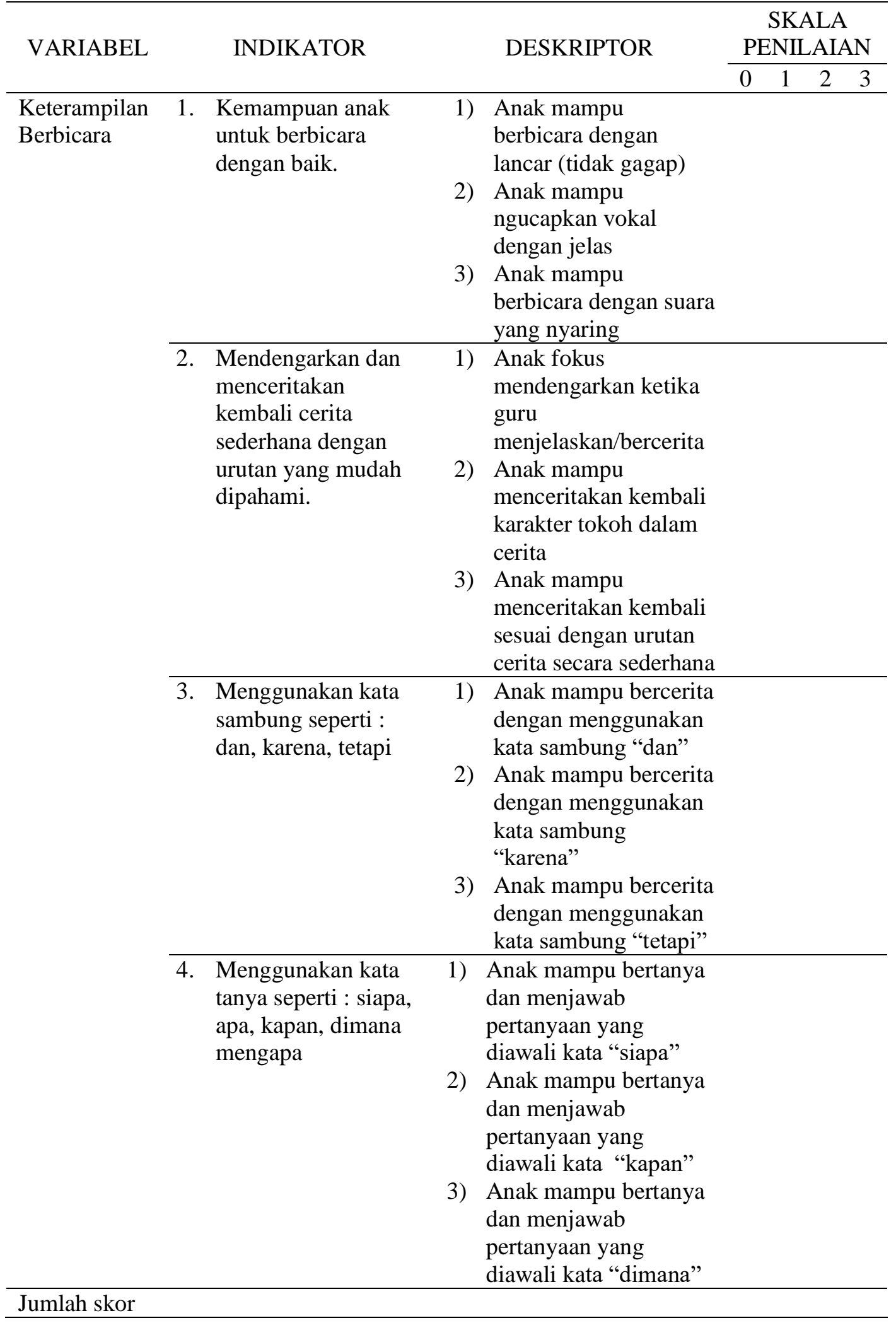




\section{Petunjuk}

Untuk memberi skor pada butir-butir kreativitas maka checklistlah angka pada kolom skor $(0,1,2,3)$ sesuai dengan kriteria berikut :

Baik sekali (BS) = jika 3 deskriptor yang tampak : skor 3

Baik (B)

$=$ jika 2 deskriptor yang tampak: skor 2

Cukup (C)

$=$ jika 1 deskriptor yang tampak: skor 1

Kurang (K)

$=$ jika tidak ada deskriptor yang tampak : skor 0

\section{HASIL DAN DISKUSI}

Telah diterangkan sebelumnya pada bab III bahwa dalam penelitian ini dikumpulkan dengan teknik observasi. Lembar observasi telah disusun sehingga dapat digunakan untuk melihat data keterampilan berbicara

Dari observasi, dapat dilihat bahwa dengan kegiatan membatik memberikan perbedaan pada perkembangan kreativitas anak di kelas kontrol dan kelas eksperimen. Perbedaan tersebut dapat dilihat dalam tabel dibawah ini

Tabel 1. Perbandingan Penerapan Metode Bermain Peran di Kelas Eksperimen (B1) dan Penerapan Metode Bercerita di Kelas Kontrol (B2)

\begin{tabular}{ccccccc}
\hline \multirow{2}{*}{ Nama Anak } & \multicolumn{2}{c}{ Kelas Eksperimen } & Nama Anak & \multicolumn{2}{c}{ Kelas Kontrol } \\
\cline { 2 - 3 } \cline { 5 - 6 } & $\begin{array}{c}\text { Nilai } \\
\text { Rata-rata Anak }\end{array}$ & Ket & & \multicolumn{2}{c}{$\begin{array}{c}\text { Nilai } \\
\text { Rata-rata Anak }\end{array}$} & Ket \\
\hline Aqil & 2 & & & Aflah & 2,5 & BS \\
\hline Athaya & 2,5 & BS & Ara & 2,25 & B \\
\hline Deva & 2,25 & B & Farish & 2,5 & BS \\
\hline Dini & 2,25 & B & Fathir & 2,25 & B \\
\hline Lila & 2,75 & BS & Fikri & 2 & B \\
\hline Nabila & 2 & B & Miftah & 2,25 & B \\
\hline Nadia & 2,75 & BS & Nabil & 2 & B \\
\hline Putri & 2,5 & BS & Rasya Y & 1,75 & B \\
\hline Rasya A & 2,5 & BS & Rifat & 2 & B \\
\hline Raziq & 3 & BS & Rizki & 2,25 & B \\
\hline Sazza & 2,75 & BS & Salsa & 1,75 & B \\
\hline Tasya & 2,5 & BS & Siti & 2,25 & B \\
\hline Zayyan & 3 & BS & Tedy & 1,5 & C \\
\hline Jumlah & $\mathbf{3 2 , 7 5}$ & & Jumlah & $\mathbf{2 7 , 2 5}$ & \\
\hline Rata-Rata & $\mathbf{2 , 5 1}$ & & Rata-Rata & $\mathbf{2 , 0 9}$ & \\
\hline Kategori & Baik Sekali & & Kategori & Baik & \\
\hline
\end{tabular}

Dari tabel diatas dapat dilihat bahwa ada perbedaan antara kelas eksperimen (pembelajaran dengan metode bermain peran) dan kelas kontrol (pembelajaran dengan metode bercerita). Pada kelas eksperimen nilai rata-rata anak diperoleh 2,51 termasuk dalam kategori Baik Sekali, dan dikelas kontrol terdapat rata-rata yang diperoleh anak 2,09 termasuk dalam kategori Baik. Dari hasil data tersebut terlihat selisih nilai rata-rata anak sebanyak 0,42 . Maka dari itu terlihat bahwa metode bermain peran yang digunakan dikelas eksperimen lebih besar pengaruhnya terhadap keterampilan berbicara pada anak dibanding kelas kontrol yang menggunakan metode bercerita. 


\section{PEMBAHASAN}

Pada proses dalam memperoleh hasil analisis data, sebelum memberikan perlakuan yang berbeda pada kedua kelas yaitu kelas kontrol dan kelas eksperimen. Peneliti melakukan sebuah observasi awal terhadap kedua kelas sampel. Setelah dilakukan perlakuan yang berbeda diperoleh skor keterampilan berbicara anak di kelas kontrol 8,38 sedangkan di kelas eksperimen 10,07. Dari hasil observasi kedua sampel tersebut diperoleh selisih 1,69 atau nilai rata-rata anak di kelas kontrol 2,09 sedangkan di kelas eksperimen 2,51 sehingga berselisih 0,42 . Dari data yang diperoleh tersebut terdapat perbedaan yang signifikan antara keterampilan berbicara anak pada kelas kontrol dan kelas eksperimen. Hal ini dapat disebabkan karena penggunaan metode bermain peran yang menarik bagi anak usia 5-6 tahun, dengan adanya sarana pembelajaran berupa metode bermain peran anak mampu berinteraksi dengan baik bersama temannya dan lebih percaya diri karena pada metode ini anak tidak dituntut akan benar salah namun memberikan motivasi yang lebih kepada anak untuk mengembangkan keterampilan berbicaranya sesuai dengan pengalaman anak sehari-hari.

Hasil penerapan metode bermain peran pada kelas eksperimen ternyata cukup memuaskan anak pada kelas eksperimen dibandingkan dengan kelas kontrol. Berdasarkan penelitian yang telah dilakukan di TK Ilmi Insani Medan dapat dinyatakan bahwa metode bermain peran dalam pembelajaran anak usia dini dapat mempengaruhi keterampilan berbicara anak.

\section{SIMPULAN}

Berdasarkan hasil penelitian dan pengolahan data pada sub bab sebelumnya dapat di ambil kesimpulan, yaitu :

1. Pembelajaran menggunakan metode bermain peran memiliki nilai rata-rata dikelas eksperimen yaitu 2,51 lebih besar dibandingkan dengan hasil observasi keterampilan berbicara anak dikelas kontrol yang memiliki rata-rata yaitu 2.09. Dapat diartikan bahwa ada pengaruh metode bermain peran terhadap keterampilan berbicara anak dari pada metode bercerita.

2. Hasil nilai uji hipotesis terbukti bahwa kelas eksperimen dan kelas kontrol diperoleh $t_{\text {hitung }}=3,869$ sedangkan $t_{\text {tabel }}=1,711$. Hal tersebut sesuai dengan hasil uji hipotesis Ho ditolak dan Ha diterima, sehingga dapat dinyatakan ada pengaruh metode bermain peran terhadap keterampilan berbicara anak usia 5-6 tahun di TK Ilmi Insani Medan.

Berdasarkan kesimpulan diatas, maka peneliti mengajukan beberapa saran yaitu :

a. Bagi pihak sekolah sebaiknya dijadikan bahan pertimbangan untuk pemilihan metode pembelajaran untuk mengoptimalkan keterampilan berbicara pada anak.

b. Bagi guru sebaiknya dapat dijadikan metode pembelajaran yang menarik untuk menarik minat anak untuk belajar dengan menggunakan metode bermain peran agar meningkatkan keterampilan berbicara anak.

c. Bagi peneliti menambah wawasan dan ilmu pengetahuan tentang apa yang telah dikaji sehingga nanti akan lebih mudah menggunakan metode bermain peran saat proses belajar anak.

\section{DAFTAR RUJUKAN}

Arikunto, Suharsimi. 2009. Manajemen Penelitian. Jakarta: Rineka Cipta.

Cahyo, Agus N. 2011. Game Khusus Penyeimbang Otak Kanan \& Kiri Anak. Jogjakarta : FlashBooks 
Dukes, Chris dan Maggie Smith. 2010. CAra Mengembangkan Keretampilan Berkomunikasi dan Berbahasa pada Anak Prasekolah. Jakarta : Indeks.

Dhieni, Nurbiana. 2012. Metode Pengembangan Bahasa. Jakarta : Universitas Terbuka

Dyer, Laura. 2004. Meningkatkan Kemampuan Bicara Anak. Jakarta : Bhuana Ilmu Populer (Kelompok Gramedia)

Eileen AK dan Lynn R. Marrotz. 2010. Profil Perkembangan Anak. Jakarta: Indeks.

Iskandarwassid, Sunendar dadang. 2010. Strategi Pembeljaran Bahasa. Bandung : Remaja Rosyadakarya.

Muhammad, Fhadlillah. 2012. Desain Pembelajaran Paud. Jogjakarta : Ar-Ruzz Media

Peraturan Menteri Pendidikan Nasional Republik Indonesia Nomor 58. 2009. Standart Pendidikan Anak Usia Dini. Jakarta: DEPDIKNAS

Saputra Yudha M \& Rudyanto. 2005.Pembelajaran Kooperatif untuk Meningkatkan Keterampilan Anak TK. Jakarta: Depdiknas

Shoimin, Aris. 2014. 68 Model Pembelajaran Inovatif dalam Kurikulum 2013. Yogyakarta : Ar-Ruzz Media.

Sudjana, Nana. 2005.Metode Statistika.Bandung: Tarsito.

Sugiono.2009. Metode Penelitian Pendidikan Pendekatan Kuantitatif Kualitatif, Dan R \& $D$. Bandung: Alfabeta.

Suhartono. 2005. Pengembangan Keterampilan Bicara Anak Usia Dini. Jakarta : Depdiknas.

Susanto, Ahmad. 2011. Perkembangan Anak Usia Dini Pengantar dalam Berbagai Aspek. Jakarta : Kencana Prenada Media Group. 